\title{
Study on the Dynamic Proliferation of JEV in BHK-21 Cells
}

\author{
Fuliang Zhang ${ }^{a, b}$ Jun Luo ${ }^{c}$ Man Teng ${ }^{c}$ Guangxu Xing ${ }^{c}$ Junqing Guo ${ }^{c}$ \\ Yihua Zhang ${ }^{\text {a }}$ \\ ${ }^{a}$ College of Veterinary Medicine, Northwest A \& F University, Yangling, China; ${ }^{b}$ College of Biology and Food \\ Engineering, Anyang Institute of Technology, Anyang, China; ${ }^{C H e n a n ~ P r o v i n c i a l ~ K e y ~ L a b o r a t o r y ~ o f ~ A n i m a l ~}$ \\ Immunology, Key Laboratory of Animal Immunology of the Ministry of Agriculture, Henan Academy of Agriculture \\ Sciences, Zhengzhou, China
}

\section{Keywords}

Japanese encephalitis virus · Proliferation profile .

Proliferation curve · Quantitative real-time PCR

\begin{abstract}
Introduction: Epidemic Japanese encephalitis is one of the most important zoonotic diseases that cause central nervous system damage. The vaccination has become the most effective and economical measure for its control. Hence, real-time monitoring of Japanese encephalitis virus (JEV) proliferation is crucial to optimize virus inoculation, culturing conditions, and virus harvest time. Methods: The proliferation dynamics of JEV in BHK-21 cells was studied by combining the established quantitative PCR method with the conventional $\mathrm{TCID}_{50}$ assay in this study. Results: The proliferation curve determined by the 2 methods has a definite parallel relationship, but the quantitative real-time PCR method $(4 \mathrm{~h})$ is faster and more sensitive than the $\mathrm{TCID}_{50}$ method (3-4 days). The determination results of $\mathrm{TCID}_{50}$ showed that the highest viral titer was $10^{5.44} \mathrm{TCID}_{50} / 0.1 \mathrm{~mL}$ and $10^{4.86} \mathrm{TCID}_{50} / 0.1 \mathrm{~mL}$ in cell suspension and culture supernate, respectively, while the virus RNA copies reached the peak at $1.0 \times 10^{7.5}$ copies $/ \mu \mathrm{L}$ and $1.0 \times 10^{5.6}$ copies $/ \mu \mathrm{L}$ in cell suspension and culture supernate, respectively. Conclusion: The comprehensive analysis showed that the best time for JEV proliferation in BHK-21 cell was $60 \mathrm{~h}$ post infection.
\end{abstract}

(c) 2021 S. Karger AG, Basel

\section{Introduction}

Epidemic Japanese encephalitis (JE) is one of the most important zoonotic diseases caused by the transmission of Japanese encephalitis virus (JEV) through mosquitoes and causes central nervous system damage. Approximately 70,000 people are infected with JE every year worldwide, of which 10,000-15,000 die [1,2]. Survivors of severe cases often leave severe sequelae. JEV is classified within the family Flaviviridae, genus Flavivirus. It is an enveloped virus containing a positive-sense singlestranded ribonucleic acid (RNA) genome approximately 11 kilobases in length. The genome encodes 3 structural proteins (capsid, pre-membrane or membrane, and envelope (E)), and 7 non-structural proteins [3-5].

There are no effective drugs for treating JE currently, and vaccination has become the most effective and economical measure for epidemic control. In the production of JEV, BHK-21 and Vero cells are mostly used for the proliferation of the virus [6-8]. As is known to all, the quality and effect of the vaccine are closely associated with the proliferation of the virus in the cell. Hence, realtime monitoring of JEV proliferation is crucial to optimize virus inoculation, culturing conditions, and virus harvest time.

$\mathrm{TCID}_{50}$ detection is currently used to determine the quantitative assay of JEV [9-11]. However, due to the

karger@karger.com
www.karger.com/int
Karger 2021 S. Karger AG, Basel


Table 1. Primers and probes used in this study

\begin{tabular}{|c|c|c|}
\hline Name & Sequences $\left(5^{\prime}-3^{\prime}\right)$ & $\begin{array}{l}\text { Amplicon } \\
\text { size, bp }\end{array}$ \\
\hline $\mathrm{JEV}-\mathrm{F}^{*}$ & $\begin{array}{l}\text { GCTGGATCC } \\
\text { CTGAAATGTAGGCTGAAAAT }\end{array}$ & 184 \\
\hline JEV-R* & $\begin{array}{l}\text { CCAAGCTT } \\
\text { TGAGGCTCGCAAGGAAACA }\end{array}$ & \\
\hline JEV-R-F** & CAACCTATGGCATGTGTA & 103 \\
\hline JEV-R-R** & CCATCACTCCCAGAGTAG & \\
\hline JEV-probe & FAM-CAATGACAACTGTTCCGTGACCA-BHQ & \\
\hline
\end{tabular}

complexity of the method, the practical application is restricted by many conditions. Nowadays, qRT-PCR has been widely used for the qualitative and quantitative detection of the virus due to its specificity, sensitivity, and accuracy [12-18], whereas qRT-PCR detects only viral nucleic acids, including inactive viruses. Therefore, the $\mathrm{TCID}_{50}$ assay is more valuable for evaluating the preparation of live virus particles, theoretically. However, for all this, if a reliable correlation is found between the above 2 methods, qRT-PCR may be possible to replace or partially replace the $\mathrm{TCID}_{50}$, which is more conducive to practical applications. In this study, a TaqMan probebased qRT-PCR analysis method was developed to monitor the proliferation of JEV in BHK-21 cells real timely, and the results of this method were compared with the results of TCID ${ }_{50}$ method. This study provides a new approach for studying the in vitro growth laws of JEV and virus detection during vaccine preparation.

\section{Materials and Methods}

\section{Cells and Viruses}

Baby hamster kidney-21 cells (American Type Culture Collection), JEV vaccine strain SA 14-14-2 (SINOLAND), PPV (porcine parvovirus), PCV2 (porcine circovirus type 2), CSFV (classical swine fever virus), PRV (pseudorabies virus), PRRSV (porcine reproductive and respiratory syndrome virus), and TGEV (transmissible gastroenteritis virus) were all kept in the College of Veterinary Medicine, Northwest A \& F University. All experiments related to egg drop syndrome virus were done in a P2 biosafety laboratory and strictly carried out according to the Laboratory Biosafety Manual in the College of Veterinary Medicine, Northwest A \& F University.
Primers and Probes Design

Multiple sequence alignments of the E gene of JEV available in GenBank were performed with Clustal-W (DNAStar Inc., Madison, WI, USA), and conserved regions were identified. Primers and probe were designed to target conserved regions of E gene by Primer Premier 5.0 (Primer Biosoft International, Palo Alto, CA, USA). All primers and probe were synthesized by Sangon Biotech. Co., Ltd (Shanghai, China). All data related to the primers and probe are shown in Table 1. A BLAST search was also conducted to verify the specificities of the primers and probe.

\section{RNA Extraction and Conventional RT-PCR}

Viral total RNA of JEV vaccine strain SA 14-14-2 were extracted using Invitrogen ${ }^{\mathrm{TM}} \mathrm{TRIzol}^{\circledR}$ Reagent (Life Technologies Corporation, Carlsbad, CA, USA) under the user guide. Viral RNA was reverse transcribed into cDNA. RT was carried out with PrimeScript ${ }^{\mathrm{TM}} 1$ st Strand cDNA Synthesis Kit (TaKaRa, Beijing, China) subsequently. The resulting cDNA was used as a template in the following PCR reactions.

\section{qRT-PCR Standard Plasmid Template Preparation}

PCR assay was carried out in a $20-\mu \mathrm{L}$ volume containing $2 \mu \mathrm{L}$ of cDNA template, $2 \mu \mathrm{L}$ primers (each $0.2 \mu \mathrm{M}$ ), $10 \mu \mathrm{L}$ Premix $\mathrm{Taq}^{\mathrm{TM}}$ (TaKaRa, Beijing, China), and $6 \mu \mathrm{L}$ RNase-free water. Amplification began with a $7-\mathrm{min}$ incubation at $95^{\circ} \mathrm{C}$, followed by 40 cycles of denaturation at $94^{\circ} \mathrm{C}$ for $1 \mathrm{~min}$, annealing at $56^{\circ} \mathrm{C}$ for $30 \mathrm{~s}$, extension at $72^{\circ} \mathrm{C}$ for $30 \mathrm{~s}$, and 1 cycle of final extension at $72^{\circ} \mathrm{C}$ for $10 \mathrm{~min}$. After examination by $1 \%(\mathrm{w} / \mathrm{v})$ agarose gel electrophoresis, the amplified fragments were digested with BamHI and HindIII and inserted into pMD ${ }^{\mathrm{TM}} 19-\mathrm{T}-$ Vector (TaKaRa, Beijing, China). The constructed plasmids were confirmed by PCR and DNA sequencing (Sangon Biotech, China). The extracted plasmids were determined by $\mathrm{OD}_{260}$ optical absorption value in NanoDrop 2000 spectrophotometer (Thermo Scientific, Waltham, MA, USA) and diluted at $1.0 \times 10^{10}$ copies/ $\mu$ L ultimately.

\section{Fluorescent Quantitative PCR Assay}

The final volume of TaqMan Probe-based fluorescent quantitative PCR is $20 \mu \mathrm{L}$, which contains $10 \mu \mathrm{L} 2 \times$ FastStart Universal 


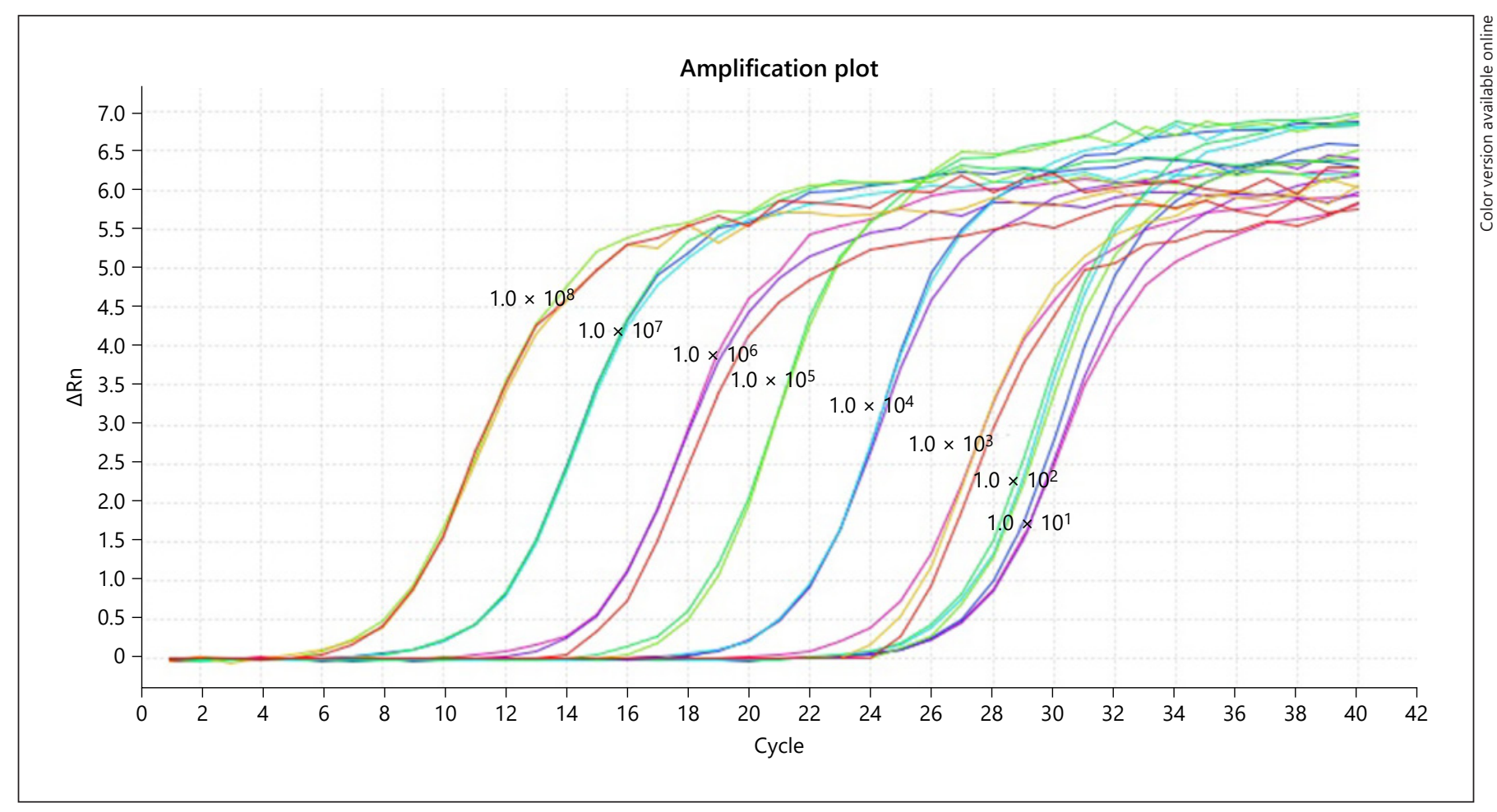

Fig. 1. The sensitivity of qRT-PCR. qRT-PCR amplification plot of 10-fold serial dilutions of standard positive plasmids DNA (from $1.0 \times 10^{8}$ copies $/ \mu \mathrm{L}$ to $1.0 \times 10^{1}$ copies $/ \mu \mathrm{L}$ ). JEV, Japanese encephalitis virus.

Probe Master (Roche), $10 \mu \mathrm{M}$ upstream and downstream each primer $0.5 \mu \mathrm{L}, 10 \mu \mathrm{M}$ probe $1 \mu \mathrm{L}$, templates $1 \mu \mathrm{L}$, and RNase-free water $6 \mu \mathrm{L}$. PCR cycling parameters were $94^{\circ} \mathrm{C}$ for $5 \mathrm{~min}$, followed by 40 cycles at $95^{\circ} \mathrm{C}$ for $15 \mathrm{~s}$ and $60^{\circ} \mathrm{C}$ for $1 \mathrm{~min}$.

Standard Curve, Sensitivity, Specificity, and Reproducibility of the Assay

To evaluate the sensitivity, 10 -folds serially diluted standard plasmid DNA (from $1.0 \times 10^{8}$ copies $/ \mu \mathrm{L}$ to $1.0 \times 10^{1}$ copies $/ \mu \mathrm{L}$ ) were used to perform the PCR. The results were compared with conventional RT-PCR. Meanwhile, to generate a standard curve of the assay, 10 -folds serially diluted standard plasmid DNA (from $1.0 \times 10^{8}$ copies $/ \mu \mathrm{L}$ to $1.0 \times 10^{4}$ copies $/ \mu \mathrm{L}$ ) were used. The standard curve of JEV detection is established by taking the logarithm of the number of starting templates as the $X$-axis and the $\mathrm{Ct}$ value as the $Y$-axis as the regression curve. The specificity was determined using RNA/DNA extracted from PPV, PCV2, CSFV, PRV, PRRSV, and TGEV, which were used as templates in parallel to evaluate the specificity of the assay.

For verifying the reproducibility, 3 different dilutions of the standard plasmid DNA $\left(1.0 \times 10^{7}\right.$ copies $/ \mu \mathrm{L}, 1.0 \times 10^{6}$ copies $/ \mu \mathrm{L}$, and $1.0 \times 10^{5}$ copies $/ \mu \mathrm{L}$ ) were tested for 10 replicates and statistically analyzed.

Comparison of the Dynamic Proliferation of JEV in BHK-21

Cells

Cell Culture and Inoculation

BHK-21 cells (inoculation concentration of $5.0 \times 10^{5}$ cells $/ \mathrm{mL}$ ) were seeded in DMEM (Gibco, UK) supplemented with $8 \%$ fetal

Dynamic Proliferation of JEV bovine serum (FBS, Hyclone, Logan, UT, USA) and cultivated for $24 \mathrm{~h}$ at $37^{\circ} \mathrm{C}$ in a $5 \% \mathrm{CO}_{2}$ incubator routinely. And then, the cells were infected with $0.1 \mathrm{~mL} \mathrm{JEV} \mathrm{at} \mathrm{a} \mathrm{titer} \mathrm{of} 10^{2} \mathrm{TCID}_{50}$ in T-25 flasks for $1 \mathrm{~h}$ at $37^{\circ} \mathrm{C}$.

\section{Virus Collection}

After incubation, the cells were washed 3 times with PBS (pH 7.2) to remove unbound virus particles and then maintained in $5 \mathrm{~mL}$ mediums DMEM containing 2\% FBS. At $0,12,24,36,48,60$, 72,96 , and $120 \mathrm{~h}$ post infection (hpi), $500 \mu \mathrm{L}$ culture supernate and cell suspension were collected from every 3 samples after frozen and thawed 3 times.

Determination of Virus Titer

qRT-PCR assay and TCID $_{50}$ determination were performed on samples taken at different time points. According to the average determination results, the proliferation curve of the virus was drawn, and comparative analysis was performed to calculate the correlation coefficient.

\section{Results}

\section{Identification of Standard Positive Plasmids}

PCR products were analyzed by $1 \%$ agarose gel electrophoresis, and a specific fragment of approximately 


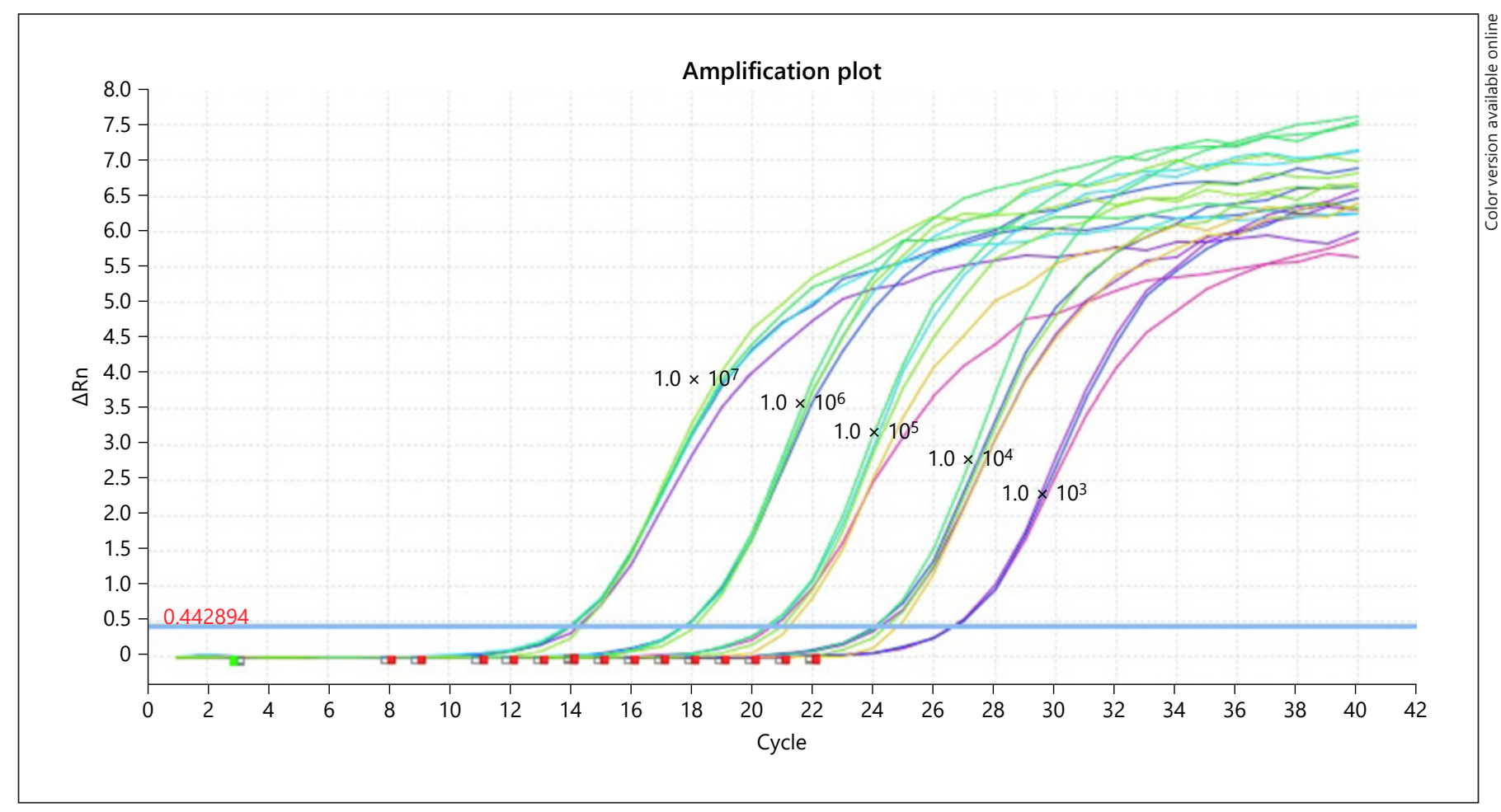

Fig. 2. Reproducibility of qRT-PCR. Amplification plot of plasmid DNA (from $1.0 \times 10^{7}$ copies $/ \mu \mathrm{L}$ to $1.0 \times 10^{3} \mathrm{copies} / \mu \mathrm{L}$ ).

1,500 bp was amplified, which was consistent with the expected results (online suppl. Fig. 1a; for all online suppl. material, see www.karger.com/doi/10.1159/000510585). The constructed plasmid DNA was digested with BamHI and HindIII, and the band of interest of about 1,500 bp and the vector of plasmid 2,700 bp were excised (online suppl. Fig. 1b). Simultaneous sequencing of the recombinant plasmids revealed that the JEV E genetic fragment had been cloned into the T-vector.

\section{Standard Curve}

The qRT-PCR amplification was performed on a 10fold serial dilution of standard positive plasmids DNA $\left(1.0 \times 10^{8} \sim 1.0 \times 10^{1}\right.$ copies $\left./ \mu \mathrm{L}\right)$ as a template. The amplification showed a good linear relationship, the standard curve equation is $\mathrm{Ct}=-3.336 \log ($ copy $\mathrm{nr})+44.18$, the correlation coefficient is 0.997 , and the amplification efficiency is $99.3 \%$ (online suppl. Fig. 2).

\section{Sensitivity, Specificity, and Reproducibility}

The analytical sensitivity of the assay was assessed through serial dilutions of standards of plasmids DNA (from $1.0 \times 10^{8}$ copies $/ \mu \mathrm{L}$ to $1.0 \times 10^{1}$ copies $/ \mu \mathrm{L}$ ). There is still a fluorescence curve of $1.0 \times 10^{1}$ copies $/ \mu \mathrm{L}$, indicating that the detection sensitivity of the method can reach $1.0 \times 10^{1}$ copies $/ \mu \mathrm{L}$. The results of the sensitivity test are shown in Figure 1. Under the same reaction system and conditions for fluorescent quantitative PCR, only JEVpositive standards showed positive signals, and other virus samples controls were negative.

In this experiment, 5 concentrations $\left(1.0 \times 10^{7}, 1.0 \times\right.$ $10^{6}, 1.0 \times 10^{5}, 1.0 \times 10^{4}$ and $1.0 \times 10^{3}$ copies $\left./ \mu \mathrm{L}, n=3\right)$ of plasmid DNA were selected as standard samples for repeated determination (Fig. 2), and the results were obtained by statistical analysis. As can be seen from Table 2, the final actual measured values of the standards at initial concentrations of $1.0 \times 10^{7}, 1.0 \times 10^{6}, 1.0 \times 10^{5}, 1.0 \times 10^{4}$, and $1.0 \times 10^{3}$ copies $/ \mu \mathrm{L}$ were $0.988 \times 10^{7}, 0.933 \times 10^{6}$, $0.975 \times 10^{5}, 0.930 \times 10^{4}$, and $0.898 \times 10^{3}$ copies $/ \mu \mathrm{L}$, respectively. The coefficients are 8.40, 5.79, 2.77, 3.33, and $3.34 \%$, respectively. The determination result indicated that the method has good accuracy and reproducibility.

\section{Proliferation Profile of JEV on BHK-21 Cells}

BHK-21 cells were infected with $0.1 \mathrm{~mL}$ JEV at a titer of $10^{2} \mathrm{TCID}_{50}$ and normal cells were used as control. The 


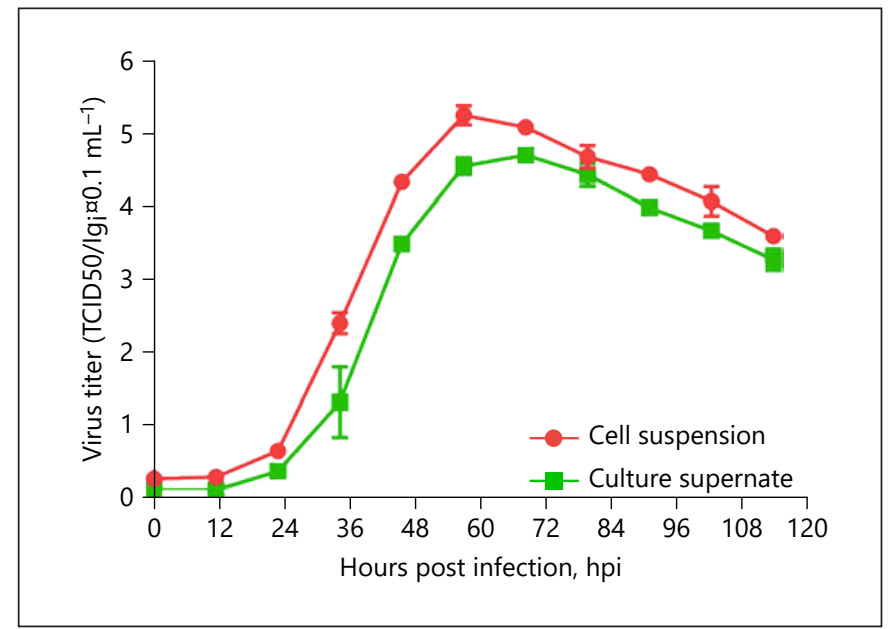

Fig. 3. One-step proliferation curve of JEV on BHK-21 cells determined by $\mathrm{TCID}_{50}$ assay. JEV, Japanese encephalitis virus; hpi, hours post infection.

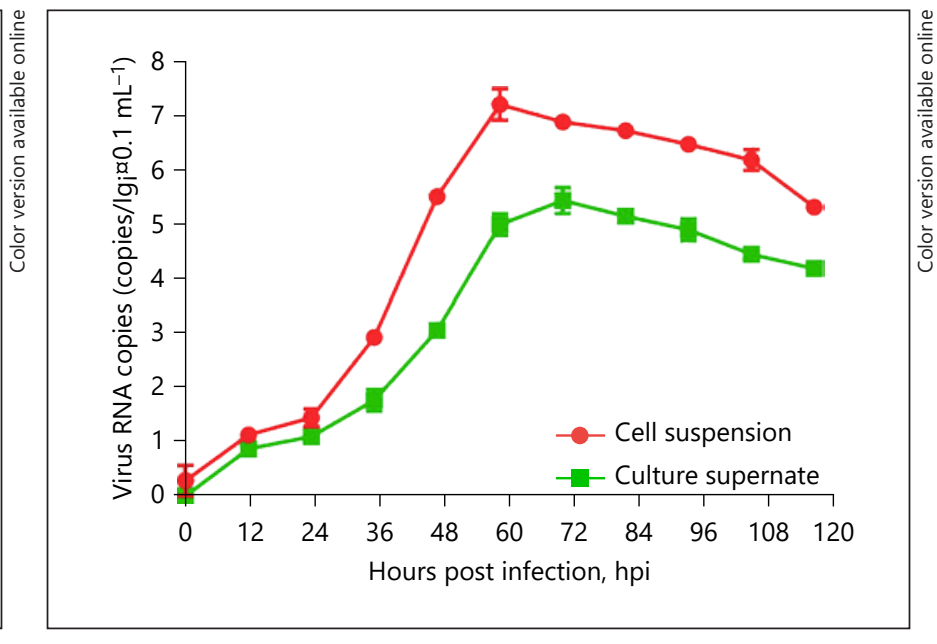

Fig. 4. One-step proliferation curve of JEV in BHK-21 cells determined by qRT-PCR. JEV, Japanese encephalitis virus; hpi, hours post infection.
Table 2. Reproducibility and recovery of the measurement of replicate standards

\begin{tabular}{llllll}
\hline \multirow{2}{*}{ Experiment } & \multicolumn{3}{l}{ Quantity, copies/ $\mu \mathrm{L}$} \\
\cline { 2 - 6 } & $1.0 \times 10^{7}$ & $1.0 \times 10^{6}$ & $1.0 \times 10^{5}$ & $1.0 \times 10^{4}$ & $1.0 \times 10^{3}$ \\
\hline 1 & 0.964 & 0.912 & 0.977 & 0.966 & 0.907 \\
2 & 0.988 & 0.893 & 1.000 & 0.916 & 0.879 \\
3 & 1.0137 & 0.995 & 0.947 & 0.909 & 0.922 \\
Arithmetic mean & 0.988 & 0.93 & 0.975 & 0.930 & 0.898 \\
Standard deviation & 0.083 & 0.054 & 0.027 & 0.031 & 0.030 \\
Coefficient of variation, $n(\%)$ & 8.40 & 5.79 & 2.77 & 3.33 & 3.34 \\
\hline
\end{tabular}

$$
\mathrm{SD}=\sqrt{\left[\left(d_{1}-x\right)^{2}+\left(d_{2}-x\right)^{2}+\cdots+\left(d_{n}-x\right)^{2}\right] /(n-1)} ;
$$

$\mathrm{CV}=S / X \times 100 \% . d n$ is the measured value and $x$ is the arithmetic mean value. $\mathrm{CV}$, coefficient of variation; SD, standard deviation. morphological changes of the cells at $0,12,24,48,60,72$, 84,96 , and $120 \mathrm{~h}$ after challenged were observed, and the cytopathic images were collected. Cytopathic effect (CPE) began to appear at $48 \mathrm{hpi}$, but it was not obvious. A small number of tiny plaques were scattered on monolayer cells; at $60 \mathrm{~h}$, the CPE was obvious, the cells shrunk, some rounded and gathered, and the cell gap increased. Cells mostly became round and began to fall off at $120 \mathrm{~h}$. Large amounts of cells shed and disintegrated in large areas moreover.

qRT-PCR assay and TCID $_{50}$ determination were performed on samples taken at different times after virus inoculation, and the virus proliferation curve was drawn (Fig. 3, 4). As shown in Figure 3, in both cell suspension and culture supernatant, the virus proliferated slowly within $24 \mathrm{hpi}$. The virus proliferation rate increased rapidly subsequently within $24 \mathrm{hpi} \sim 60 \mathrm{hpi}$, with the viral load increasing logarithmically. The viral titer reached the highest level of $10^{5.44} \mathrm{TCID}_{50} / 0.1 \mathrm{~mL}$ in cell suspension at $60 \mathrm{hpi}$ and $10^{4.86} \mathrm{TCID}_{50} / 0.1 \mathrm{~mL}$ in culture supernate at $72 \mathrm{hpi}$, respectively. The peak of viral titer is $12 \mathrm{~h}$ ahead in cell suspension than in culture supernate. After that, the content of JEV showed a decreasing trend up to $120 \mathrm{~h}$, but the decline rate was slow. The dynamic curves of virus titer of JEV on BHK-21 cells were very similar in both cell suspension and culture supernate.

As shown in Figure 4, the amount of JEV presented a tendency of straight climb with the increase of hpi either 
in cell suspension or in culture supernate. And the viral load in culture supernate is less than that in cell suspension continuously. The virus RNA copies reached the peak at $1.0 \times 10^{7.5}$ copies $/ \mu \mathrm{L}$ and $1.0 \times 10^{5.6}$ copies $/ \mu \mathrm{L}$ in cell suspension is and culture supernate, respectively. The peak appeared in cell suspension is $12 \mathrm{~h}$ ahead than in culture supernate. The virus RNA copies reduced slowly after the limit value. Combining with Figures 3 and 4, it can be seen that the uptrend and the peak of the proliferation profile of JEV inoculated on BHK-21 cells measured by $\mathrm{TCID}_{50}$ determination are consistent with which measured by qRT-PCR assay. Meanwhile, the correlation coefficient between the quantitative copy number and the TCID50 data was $r=0.867$ and $r=0.888$ in the cell supernatant and cell suspension, respectively.

\section{Discussion}

qRT-PCR could be used for quantitative detection of virus contained in a unit volume. However, it should be noted that the viral load measurement just reflected the amount of viral nucleic acid contained in the test and could not reflect the amount of live virus or intact virus particles. Virus titer is usually expressed as $\mathrm{TCID}_{50}$, which could reflect the number of viruses with biological activity or function. The primitive and classical method for the quantitative detection of JEV is to determine its $\mathrm{TCID}_{50}$. However, its practical application is subject to many conditions.

The standard curve of qRT-PCR assay explored in this test showed a good linear relationship at $1.0 \times 10^{8} \sim 1.0 \times$ $10^{1}$ copies $/ \mu \mathrm{L}$, with the correlation coefficient 0.997 and the amplification efficiency $99.3 \%$, which provides basic data for precise analysis of virus replication in cells.

The proliferation dynamics of JEV on BHK-21 cells determined by qRT-PCR and TCID 50 assay showed that the number of virions or virus titer of the cell suspension was significantly higher than that of the culture supernatant and reached the peak at first. This is because some cells contracted and fell off and entered into the cell supernatant after $24 \mathrm{hpi}$. Both of them reached the peak at $60 \mathrm{hpi}$ and then began to fall. However, the TCID 50 value decreased slightly after $60 \mathrm{hpi}$ which may be because the value measured by the qRT-PCR contained 3 types of viral nucleic acids, including live virus (infectious) nucleic acids, inactivated viruses (non-infectious but antigenic and immunogenic) nucleic acids, and nucleic acids of virion that have not yet completed assembly. While the $\mathrm{TCID}_{50}$ value only determined the titer of live virions.
The proliferation curve determined by the 2 methods has a certain parallel relationship, but the quantitative PCR $(4 \mathrm{~h})$ is faster and more sensitive than the TCID 50 assay ( $3 \sim 4$ days), and it is more suitable for rapid determination of JEV proliferation titer real timely. The comprehensive analysis showed that the best time for receiving JEV proliferated on BHK-21 cells was at 60 hpi. Nevertheless, the peak of virus proliferation was closely related to various factors, the proliferation curve of different virus strains needed to be studied systematically. However, this study will provide technical support for the preparation of high-titer virus solution or production of JEV.

\section{Statement of Ethics}

Not applicable. There are no human and animal subjects in this study.

\section{Conflict of Interest Statement}

The authors have no conflicts of interest to declare.

\section{Funding Sources}

This work was supported by the National Key Research and DevelopmentProgramofChina(grantnumbers2016YFD0500701), the Earmarked Fund for Modern Agro-industry Technology Research System of China (grant numbers CARS-35), and the Special Fund for Henan Agriculture Research System (grant numbers S2012-06-02).

\section{Author Contributions}

Y.H.Z. planned and designed the research. F.L.Z. and J.L. finished the experiments. M.T. and G.X.X. performed the data analysis. J.Q.G. prepared the reagents used in the experiments. F.L.Z. wrote the manuscript. All authors have read and approved the manuscript.

\footnotetext{
References

1 Impoinvil DE, Ooi MH, Diggle PJ, Caminade C, Cardosa MJ, Morse AP, et al. The effect of vaccination coverage and climate on Japanese encephalitis in Sarawak, Malaysia. PLoS Negl Trop Dis. 2013 Aug;7(8):e2334

2 Gao X, Liu H, Li X, Fu S, Cao L, Shao N, et al. Changing geographic distribution of Japanese encephalitis virus genotypes, 1935-2017. Vector Borne Zoonotic Dis. 2019 Jan;19(1):35-44.

3 Chambers TJ, Hahn CS, Galler R, Rice CM. Flavivirus genome organization, expression, and replication. Annu Rev Microbiol. 1990; 44(1):649-88.
} 
4 Rauscher S, Flamm C, Mandl CW, Heinz FX, Stadler PF. Secondary structure of the $3^{\prime}$-noncoding region of flavivirus genomes: comparative analysis of base pairing probabilities. RNA. 1997;3(7):779-91.

5 Honjo S, Masuda M, Ishikawa T. Effects of the Japanese encephalitis virus Genotype V-derived sub-viral particles on the immunogenicity of the vaccine characterized by a novel virus-like particle-based assay. Vaccines. 2019 Aug;7(3):81.

6 Kallel H, Jouini A, Majoul S, Rourou S. Evaluation of various serum and animal protein free media for the production of a veterinary rabies vaccine in BHK-21 cells. J Biotechnol. 2002;95(3):195-204.

7 Fujinaga K, Gershon R, Prince A. Comparative evaluation of stable line monkey kidney cells for study of Japanese encephalitis virus (JEV). Jpn J Exp Med. 1964;34(1):1-15.

8 Melvin MA, Wallace HM, Keir HM. Conjugation of polyamines in mammalian cells in culture. Physiol Chem Phys. 1980;12(5):4319.
9 Wang ST, Wang XW, Chen L, Zhao J, Chang HT, Yang X, et al. Proliferation dynamic of Japanese encephalitis virus in vitro using a newly developed fluorescent quantitative PCR assay [J]. Chin J Vet Sci. 2013;6.

10 Teng M, Luo J, Fan JM, Wang XT, Wang FY, Chai SJ, et al. Isolation and propagation of a field Japanese encephalitis virus isolate CSF. XZ-2D from swine. Chin J Prev Vet Med. 2012;4.

11 Wang ST, Li WH, Wang CQ, Liu HY, Wang XW, Chang HT, et al. Study on the physicochemical properties and proliferative characteristics in BHK-21 cells of Japanese encephalitis virus LS strain. China Anim Husb Vet Med. 2013;40(3):134-6.

12 Sun YW, Liu JY, Xu WJ, Tian Y, Wang JY, Song CX. Detection of JEV by fluorescent quantitative PCR. Prog Vet Med. 2007;(8):5.

13 Zhu SF, Zhu RL, Qiao CX, Gao ZQ, Zhuang LF, Zhuang HX, et al. Development of fluorescence quantitative PCR assay to detect $\mathrm{gB}$ gene of pseudorabies virus. Chin J Vet Sci. 2012;32(10):1413-7.
14 Wang SS, Li YB, Meng XL, Ma F. Development of SYBR Green I fluorescence quantitative RT-PCR assay for detection of porcine reproductive and respiratory syndrome virus. Acta Agric Univ Jiangxiensis. 2009;6.

15 Shirato K, Miyoshi H, Kariwa H, Takashima I. Detection of West Nile virus and Japanese encephalitis virus using real-time PCR with a probe common to both viruses. J Virol Methods. 2005;126(1-2):119-25.

16 Santhosh SR, Parida MM, Dash PK, Pateriya A, Pattnaik B, Pradhan HK, et al. Development and evaluation of SYBR Green I-based one-step real-time RT-PCR assay for detection and quantitation of Japanese encephalitis virus. J Virol Methods. 2007;143(1):73-80.

17 Toriniwa H, Komiya T. Rapid detection and quantification of Japanese encephalitis virus by real-time reverse transcription loop-mediated isothermal amplification. Microbiol Immunol. 2006;50(5):379-87.

18 Yang DK, Kweon CH, Kim BH, Lim SI, Kim $\mathrm{SH}$, Kwon JH, et al. TaqMan reverse transcription polymerase chain reaction for the detection of Japanese encephalitis virus. J Vet Sci. 2004 Dec;5(4):345-51. 